\title{
6.23 Актуальність формування інформаційної грамотності учнів закладів загальної середньої освіти на уроках географії профільного рівня
}

Одна 3 основних цілей розвитку інформаційного суспільства в Україні - забезпечення комп’ютерної та інформаційної грамотності населення. На виконання поставленої мети спрямовані завдання - створення системи освіти, орієнтованої у формуванні компетентного, всебічно розвиненого випускника, використання інформаційно-комунікаційних технологій (IКT) у сукупності методів, прийомів, спрямованих на підготовку особистості інформаційного суспільства, формування інформаційної грамотності, дослідницьких умінь роботи з інформацією, розвиток комунікаційних здібностей, добір оптимальних рішень щодо раціонального використання електронних засобів навчального призначення (ЕЗНП) у пошуку необхідної географічної інформації тощо.

Динамічні зміни в суспільстві зумовлюють необхідність постійної роботи над собою кожної людини. Особливо актуальним це питання є для педагога як фахівця, коуча, фасилітатора змін, транслятора нових ідей, мобільного консультанта учнів нової української школи (НУШ). Зважаючи на це, перед сучасним учителем географії постають завдання щодо оптимального поєднання форм, методів, засобів побудови освітнього процесу з географії, мотивування вихованців до стійкого інтересу щодо переосмислення інформації та використання нових форм ії подання.

У такий спосіб, нагальною потребою сучасної школи є створення організаційно-процесуальних умов (побудова процесу навчання, що уможливлює використання ІКТ, геоінформаційних систем (ГІС) в освітній діяльності), навчально-методичних умов (розробка та використання посібників, підручників; віртуальних лабораторій, практикумів; електронних тестуючих систем; інтерактивних географічних карт; диференційованих i компетентнісно орієнтованих завдань; спільний з учнями добір інструментів навчання; використання вчителями педагогічнх програмних засобів (ППЗ), освітніх інтернет-сервісів, відповідно до мети заняття тощо), за яких кожен учасник освітнього процесу мав би змогу самостійно здобувати необхідну 
інформацію, використовуючи іiї для власного розвитку, самореалізації, розв'язання навчальних проблем, формування самоосвітньої, геоінформаційної компетентності.

Питання інформатизації освітнього середовища, застосування IКТ,

своїх працях розглядали: В. Бондаренко [577], I. Варфоломєєва [574], М. Грузман [576], Д. Гукін [579], А. Гуржій [577], М. Жалдак [581], М. Камедія [582], Д. Корчевський [585], О. Ляшенко [587], Н. Морзе [581], О. Співаковський [577], В. Тарадайник [589], I. Шахіна [582] та ін.

Дидактичні аспекти формування інформаційної грамотності у процесі навчання географії у своїх роботах висвітлили: Н. Гончарова [575], В. Гудима [578], Л. Даценко [580], С. Кобернік [583]， Р. Коваленко [583], В. Корнєєв [584], К. Костиря [586], А. Некос [588], В. Остроух [580] та ін.

Однак, аналіз останніх досліджень і публікацій за обраним напрямом указує на те, що на додатковий розгляд заслуговують питання використання IКТ на уроках географії профільного рівня, у тому числі у контексті вимог НУШ.

Метою статті $\epsilon$ висвітлення питання значимості та особливостей використання IКТ, ЕЗНП, що дають змогу ефективно, зокрема, за допомогою використання інтернет-сервісу Learning Apps, програмного забезпечення Microsoft Office та вільної кросплатформеної геоінформаційної системи QGIS, формувати інформаційну грамотність учнів на уроках географії в закладах загальної середньої освіти (33СО) на сучасному етапі розвитку освіти.

Значні можливості в технополізованому світі перед учителем відкриває використання Інтернет матеріалу - ефективний спосіб зв'язку навчання географії 3 життям, трудовою діяльністю населення; засіб активізації пізнавальної діяльності школярів у процесі навчання, підвищення його виховного потенціалу, за умов ефективного використання Internet-pecyрсів і програмного забезпечення (Microsoft Office: Microsoft Office Word, Microsoft Office Excel, Microsoft Office PowerPoint, Microsoft Office Publisher Microsoft Office Outlook, Microsoft Office Access, Microsoft Office OneNote, Microsoft Office FrontPage, Microsoft Office Visio, Microsoft Office Project), ГІС, ЕЗНП, ППЗ [591]. 
У разі використання комп’ютера як засобу навчання та побудови процесу комунікації в єдності всіх його компонентів (комунікатор, інформація, комунікант, засоби, результат зворотного зв'язку) на уроках географії профільного рівня стають можливими: індивідуалізація та диференціація процесу навчання; здійснення контролю за зворотним зв'язком i результативністю роботи; здійснення самоконтролю та самокорекції; унаочнення (демонстрація динаміки процесів, що вивчаються; графічна інтерпретація досліджуваних закономірностей) навчального матеріалу; моделювання, імітація процесів, які вивчаються та досліджуються, явищ із «переходом» у «реальність - модель» і навпаки; проведення практичних робіт у режимі «приєднання» за допомогою спеціальних пристроїв демонстраційного обладнання до комп'ютера; створення та використання інформаційних баз даних, необхідних в освітній діяльності, забезпечення доступу до мережі інформації; посилення мотивації навчання; «озброєння» учнів стратегією засвоєння навчального матеріалу; формування відповідного стилю мислення, уміння обирати варіанти розв'язання завдань; розвиток творчих здібностей особистості; осучаснення процесу навчання географії з урахуванням психологопедагогічних особливостей учнів; формування компетентного випускника НУШ тощо [590].

Вихідною умовою, що забезпечує ефективне використання матеріалу інтернет-ресурсів на уроках географії, $є$ добір його змісту за сукупністю таких критеріїв: наукова достовірність, доступність для розуміння, коректність поданих формулювань, відповідність навчальним програмам із географії, своєчасність та актуальність презентації тощо.

Навчальною програмою з географії передбачено, що випускники НУШ мають: розвинений пізнавальний інтерес, інтелектуальні та творчі здібності, провадити самостійну навчальну діяльність шляхом пошуку та обробки географічної інформації, тобто набувати геоінформаційної компетентності сукупно з інформаційною грамотністю. Тож, навчання за допомогою комп’ютера та IKT упевнено торує шлях у методиці навчання географії. Застосування IКТ у 
навчанні географії- одна 3 методологічних проблем та потреб сьогодення. Навчання географії за допомогою ІКТ $є$ ефективним під час вивчення всіх шкільних курсів географії (від пропедевтичних до тих, що вивчаються на профільному рівні) й особливо курсів за вибором (на кшталт «Lean-логістика в географії»), адже сприяє унаочненню програмового матеріалу, кращому розумінню та засвоєнню абстрактних понять, формуванню в учнів практичних умінь просторової орієнтації, навичок віртуалізації, візуалізації.

Таким чином, на уроках географії учитель має можливість використовувати IKT із метою: пропедевтики навчання географії на профільному рівні, розкриття особливостей та закономірностей розвитку географічних і соціально-суспільних явищ; унаочнення певної інформації; комплексної характеристики території та виокремлення й опису типових її особливостей; демонстрації тематичних схем, карт, графіків, таблиць; контролю та корекції знань, умінь і навичок учнів; проведення навчальних географічних ігор; конструювання просторових моделей логістичних потоків; здійснення віртуальних подорожей і відкриттів та ін.

Сучасний урок географії в старшій школі неможливо уявити без використання мультимедійних технологій, учителю дедалі складніше вдосконалювати освітній процес без використання комп’ютера як засобу навчання. Урок із застосуванням мультимедійних технологій стає цікавішим для учнів, а отже, ефективнішим для засвоєння знань, відпрацювання умінь та набуття навичок, формування мотиваційних установок. Актуальною в цьому контексті є медіаосвіта, яка орієнтована на підготовку молоді до життя в нових інформаційних умовах. Швидкий розвиток ІКТ відкриває людству нові можливості в освіті, висуваючи, натомість, нові вимоги до навчання та того, хто навчає. Розвиток так званого інформаційного простору вимагає від сучасної школи модифікації окремих аспектів її діяльності, які вже не задовольняють усіх потреб інформаційного суспільства. Навчання медіа грамотності, критичного мислення учнів - аспекти вивчення географії на профільному рівні, засновані на процесах формування практичних навичок розуміння, аналізу, оцінювання 
змісту медіа продукту; здатності створювати власний медіа продукт, оцінювати власну медіа активність тощо [591].

Нині учні старших класів, особливо ті, що навчаються на профільному рівні, мають бути не лише ознайомлені з таким поняттям, як презентація, а вміти іï будувати та модифікувати з елементами анімації; не лише орієнтуватися в тому, що таке QR-код, а усвідомлювати його значення та вміти створювати й інтерпретувати; не тільки розумітися у просторових поняттях, а й уміти конструювати просторові моделі за допомогою IKT; не лише знати, що таке інтернет-ресурси, а використовувати їх у власній освітній діяльності, що, у свою чергу, доцільно використовувати вчителям на уроках географії 3 метою зацікавлення предметом, осучаснення процесу навчання, задоволення потреб учнів, зокрема щодо роботи з ЕЗНП.

Важливим аспектом у формуванні геоінформаційної культури, предметної географічної компетентності учнів старших класів відіграє правове виховання, яке за допомогою ЕЗНП може бути використано з метою навчання культури цитування, уміння посилатися в презентації на використані джерела інформації.

Використання анімації як засобу візуалізації на уроці географії сприяє акцентації уваги учнів на важливих фактах, подіях; посиленню зацікавленості змістом навчання. Так, у презентації PowerPoint доцільним є додавання анімації до тексту, фігур, таблиць, рисунків SmartArt та інших об’єктів із метою створення візуальних ефектів, зокрема ефектів входу й виходу, зміни розміру або кольору та навіть руху. Однак, у PowerPoint не слід плутати анімацію 3 переходами (ефекти типу: «вхід», «вихід», «виокремлення», «шляхи переміщення»). У процесі створення презентації як засобу навчання доцільним $€$ використання кількох прийомів реалізації ефекту анімації, один із яких - прийом типу «накладання», за допомогою чого реалізується ефект динамічного зображення. Застосування прийому «накладання» буде доцільним у процесі вивчення навчальної теми «Україна в міжнародному просторі» (10-й клас). У такий спосіб, на карту світу послідовно наносять країни і території, дотичні до території України, що утворилися в різні історичні періоди, i, поступово, - дедалі 
віддаленіші територіально. Прийом накладання, у переважній більшості, лежить в основі вправ настільних ГIC (QGIS), основним призначенням яких є обробка та аналіз просторових даних, підготовка різної картографічної продукції засобами пакету з інтерфейсу QGIS, що має гнучку систему розширень, завдяки чому можливим є побудова географічних карт із растрових і векторних шарів [588]. Типовим для такого роду програмного забезпечення є збереження векторних даних у вигляді площинного (материк, країна, озеро тощо), лінійного (магістралі тощо), крапкового (населені пункти тощо) зображення. Використання різних картографічних проєкцій дозволяє створювати географічні карти відповідного масштабу, тематики, змісту з поетапним нашаруванням необхідної конфігурації.

Аналогічно прийому накладання, у побудові географічних карт засобами ГІС шляхом 3(2)D-моделювання (простору, об'єкту тощо), можуть бути використані прийоми типу «приховування» або «виникнення». Об'єктами такого анімаційного ефекту можуть бути схеми, блок-схеми, частини лінійного тексту. Зокрема, такі анімаційні прийоми можна використати під час вивчення навчальних тем: «Населення України», «Економіка України у міжнародному поділі праці» (11-й клас), у яких значну кількість інформації подано в таблицях, опорних схемах, а використання елементів анімації дасть змогу тримати увагу учнів під час вивчення одноманітного статистичного навчального матеріалу [591].

Ще один прийом - типу «рух у просторі» - може бути використаний у процесі навчання географії, у поєднанні з ГІС, з метою ілюстрації туристичних маршрутів, пам’яток світової культури, історії, архітектури, археології, природи, населення та ін.

Використання ЕЗНП, ІКТ, ГІС на уроках географії в старших класах школи має свої особливості та закономірності. Так, критично оцінюючи інформацію, учні аналізують іiі на предмет головного та другорядного тексту в змісті; вибудовуючи презентацію, логічно добирають інструменти іiі побудови, використовуючи водночас інші засоби навчання (текстові, графічні, об'ємні тощо); порівнюють (екстраполюють на свою місцевість), узагальнюють, роблять 
висновки та умовиводи. Це сприяє формуванню в учнів навичок стисло, зручно для ефективної інтерпретації, представляти результати досліджень за допомогою IКТ, ГІС, майндмеппінг-софту, хотлисту, мультимедіа скрепбуку, бук-трейлерів, вдало дібраних діаграм і графіків, переконливих фактів для віртуальної демонстрації процесів, явищ, подій тощо. Осучаснює процес навчання географії використання інтернет-сервісу Learning Apps та вільної кросплатформеної геоінформаційної системи QGIS, як сучасного засобу навчання. До прикладу подібного поєднання - розроблений нами E-збірник «Lean-логістика в географії» у формі бук-трейлера, окремі сторінки якого доповнено прикладами мультимедіа скрепбуку інтерактивних вправ засобами Print Screen-візуалізації логістичного лото [591].

У такий спосіб, специфіка використання IKT на уроках географії визначається, удосконаленням системи національної освіти; зумовленістю таких стратегічних ліній, як інформаційна спрямованість змісту навчання, ऑii невід'ємність від світових надбань. Істотне зростання обсягу наукових знань позначається на обсягах інформаційної складової процесу навчання географії на профільному рівні, у свою чергу, потребуючи розвитку й модернізації методів трансляції, за допомогою IКТ. Сучасні прогресивні тенденції в освіті, зокрема компетентнісний підхід, зорієнтовують суб’єктів освітньої діяльності на багатоаспектну різнобічну змістову інтеграцію, використання IКТ, ЕЗНП, ГІС, які відображають динамізм нової наукової парадигми та педагогічної думки, синтезують багатогранність їх внутрішніх зв’язків і взаємозалежностей.

У такий спосіб, значні можливості щодо використання IКТ у різних видах діяльності мають учні старшої школи, за умов наявної матеріально-технічної бази, відповідних навичок роботи, мотивації, підтримки вчителів, навчаючись за програмами рівня стандарту, академічного, профільного. На підставі викладеного можна зробити висновок, що проблема підготовки вчителів до процесу створення та використання засобів навчання географії має міждисциплінарний характер. У такий спосіб, актуалізується питання тенденцій удосконалення професійної підготовки учителів географії у системі 
післядипломної освіти у контексті імплементації концептуальних засад НУШ у практику роботи 33СО та методичного обгрунтування системи засобів навчання географії на профільному рівні, що є предметом подальших наших наукових розвідок. 